DOI - https://doi.org/10.5965/2316796310192021003

\title{
USER EXPERIENCE EVALUATION IN THE HURBANIZE APP UNDER NINE SOURCES OF PRODUCT EMOTION
}

\author{
Fernando Souza Ferreira' \\ Gabriela Zubaran de Azevedo Pizzato² \\ Jocelise Jacques de Jacques ${ }^{3}$ \\ Júlio Carlos de Souza van der Linden ${ }^{4}$
}




\begin{abstract}
Ideas to boost the redemocratization of urban spaces are urgent and essential. This study aims to evaluate the user experiences in the app "Hurbanize: share ideas for the city". The research presented four moments and separated thirty participants into three groups. Data collection employed Pick-A-Mood, explanation of emotions and user experience qualifications. Data analysis is made by the mood model of arousal and valence, using appraisal theory and nine sources of product emotion. The results present an increase in arousal and valence as well as perceptions of affinity, displeasure, credit, claim, apprehension, and enjoyment towards the Hurbanize app.
\end{abstract}

Key-words: User experience. App. Appraisal theory. Urban renewal. Tactical urbanism.

${ }^{1}$ fernanlferreira@gmail.com

${ }^{2}$ gabriela.zubaran@ufrgs.br

3 jocelise.jacques@ufrgs.br

4 julio.linden@ufrgs.br 


\section{INTRODUCTION}

It is estimated that by the year 2050, $68 \%$ of the world's population will live in urban areas (UNITED NATIONS, 2018). This space, characterized by constant transformation, must be able to grant well-being and happiness for its people (CULLEN, 2008). However, throughout the 20th century, the increases in housing and individual vehicles have deprived people from common and interacting spaces in cities (GEHL, 2013; JACOBS, 2011). Recently, driven by the development of new technologies, citizens have started to emphasize their desire for better living and belonging conditions. However, in Brazil, this social action still has low expressivity (BARATA; FONTES, 2016). There is a shortage of ideas and proposals by Brazilian politicians, specialists, and the community for the safe, sustainable, and healthy development of cities (LERNER, 2017). One of the possible solutions to change this situation is sharing "a correct view", "a scenario", or "a desirable design" so that "everyone" can believe and decide on the city's collective construction (LERNER, 2003, p. 67).

In this context, the Progressive Web App (PWA) Hurbanize was designed to enable the discussion of ideas for the city through visual compositions made by the citizens of a location (SOUZA FERREIRA, 2017). It allows mobile device's users to photograph an urban space, choose an area by painting over it and apply urban elements illustrated on the photograph. Such a creative, open, and interactive process aims to: "use visual language to sharpen citizens' values and perceptions of what each individual realizes as one's urban ideal"; "encourage citizen's apprehension of space from the arrangement and composition of virtual elements"; and promote awareness for engagement and to value promotion, becoming "a channel for consultation and exchanging among citizens and between citizens and specialists" (SOUZA FERREIRA et al., 2019, p. 15).

The goal of this research is to assess user experience in the Hurbanize PWA, which enables citizens to share ideas for their cities. The research presents the app's characteristics organized by Souza Ferreira (2017); the appraisal theory proposed by Desmet (2002) as well as the nine sources of product emotion elaborated by Desmet (2007). This is followed by: (i) the research strategy, which develops an experiment divided in thirteen steps and four moments with thirty participants; and (ii) data analysis, with emphasis on the third moment, which brings the derivation of thirty responses into seventy-two perceptions, which are classified and interpreted through the relationship among product, usage and consequence stimuli with attitude, goals, and standards. Final considerations state that the app's proposal was accepted by the research participants, however the product should be improved and receive new features.

\section{THEORETICAL BACKGROUND}

Next, theories applied to the Hurbanize app as well as the theoretical bases for evaluating products under emotional biases are presented.

\subsection{Hurbanize: share ideas for the city}

Hurbanize (Figure 1) is a PWA in its first phase of software development (alpha version). It is the result of a Design graduate's final paper at Federal University of Rio Grande do Sul (UFRGS), which gained recognition by Tomie Ohtake Institute's "Share"

HFD, v.10, n 19, p. 03-28, junho 2021 
exhibition (INSTITUTO TOMIE OHTAKE, 2019) and is based on the theoretical proximity amongst concepts of tactical urbanism, collage, and interaction design (SOUZA FERREIRA et al., 2019).

Figure 1 - PWA Hurbanize alpha version interfaces
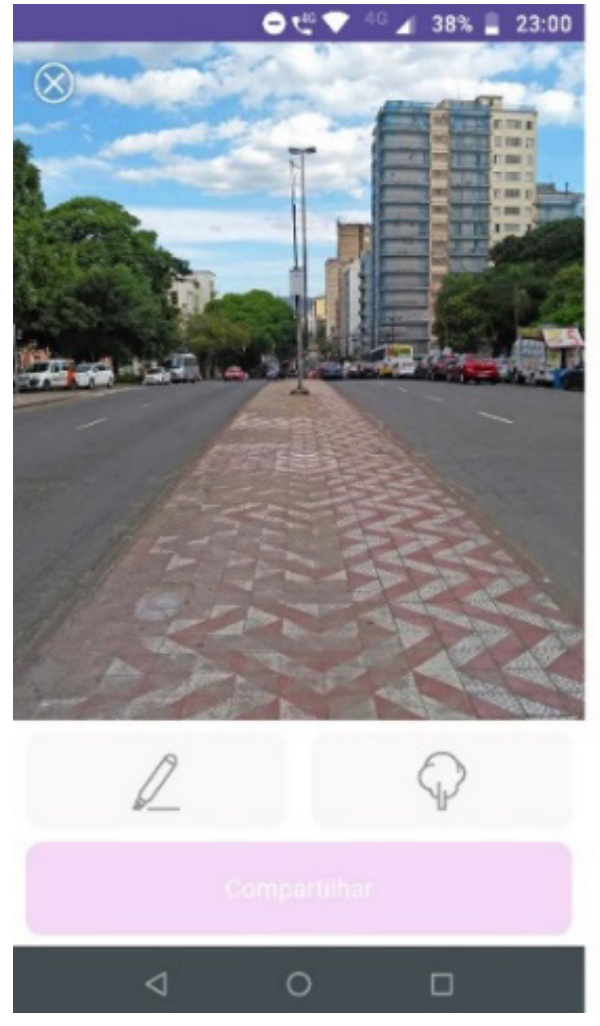
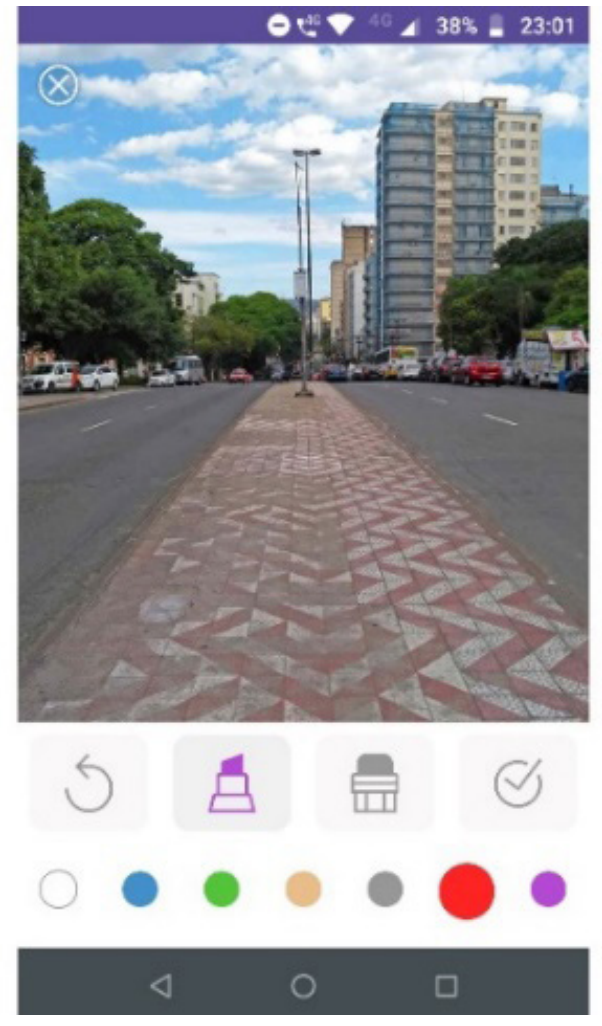

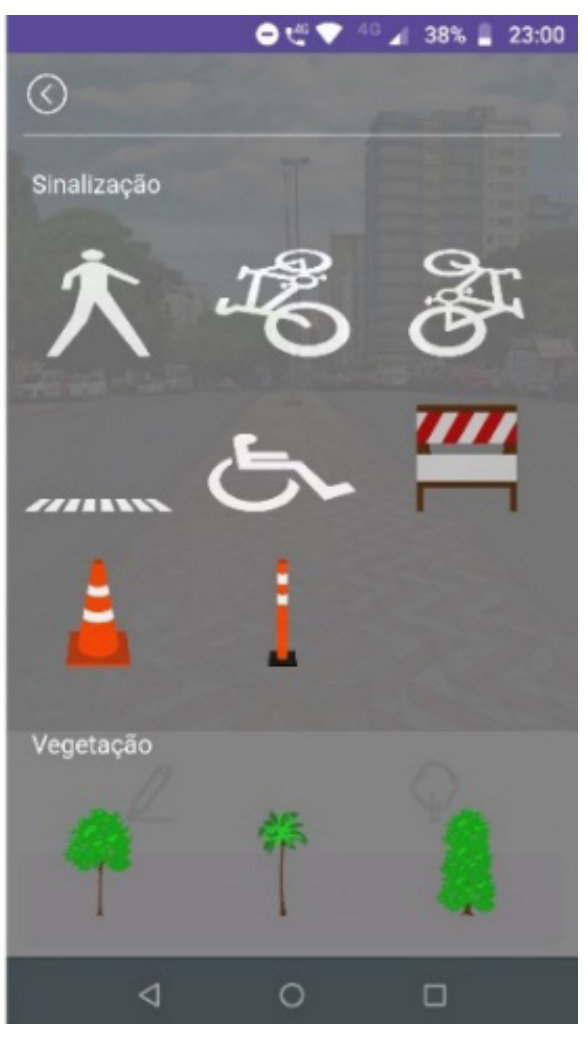

Source: The authors.

Tactical urbanism aims to study long term and large-scale change possibilities in urban spaces through quick and easy-to-execute interventions (LYDON \& GARCIA, 2016). It consists of three common applications: (i) citizens' initiative (models, prototypes, and visual idealizations), (ii) government tools (citizen engagement) and (iii) "phase 0" implementation (pilot projects for investment evaluation) (LYDON \& GARCIA, 2015). Therefore, the first common use of tactical urbanism applies to Hurbanize, that is, the citizens' initiative to present visual solutions and, without imposing limits, it can also meet the second common use of tactical urbanism, which is citizen's engagement via government (SOUZA FERREIRA, 2019).

Collage allows modifying elements' significance and appearance, usually using printed graphs and photographs, through the creation of compositions (FUÃO, 2011). It is a conscious and dynamic action by the observer towards a picture of the space (FUÃO, 1992) and aims to remove the superficiality of elements to reveal an idea to the world through the relations of the "wandering" and the "waiting" - the "wandering" are the selected figures and the "waiting" is the scenario or support chosen to receive the "wandering" elements (FUÃO, 2011). Thus, Hurbanize app provides illustrated urban elements ("wandering") and allows users to photograph a scene of the urban space 
("waiting"). Therefore, each illustration chosen in the app as well as each urban setting chosen by the user reveals the clear intention to communicate an idea (SOUZA FERREIRA et al., 2019).

Interaction design is understood as an interface that creates new usage and experiences, which expand the way people communicate, work, and interact, highlighting the growing mix of physical and digital environments, such as: mixed realities, augmented realities, tangible interfaces and interfaces that support interactions (PREECE et al., 2013). Hurbanize takes advantage of interaction to promote a new relationship between users and their urban spaces, mediating the real (photography) and the fictitious (illustrated urban elements) through a digital interface (SOUZA FERREIRA et al., 2019).

\subsection{Appraisal theory and nine sources of product emotion}

The role of emotions in design can be understood through the most diverse models, with emphasis on those developed by Desmet (2002), Jordan (1999) and Norman (2004). This research will use the Appraisal Theory, proposed by Desmet (2002), which explores the emotional relationship between people and products through the cognitive theory of emotions (DESMET, 2002; 2007; TONETTO, 2012). From this perspective, users evaluate stimuli according to their personal meaning (DESMET, 2007). This process occurs through the relationship among appraisal, concern, and product (DESMET, 2002). Appraisals are intuitive assessments that create significance for a certain product; this meaning depends on the user's concerns, which are the previous references owned by a person; and such concerns determine how a product is perceived by an individual - whether positively or negatively (DESMET, 2002; 2007; TONETTO, 2012). Therefore, an interaction (Figure 2) among the product and the user's concerns results in appraisals, which result in emotional reactions (DESMET, 2002).

Figure 2 - Appraisal model of product affect

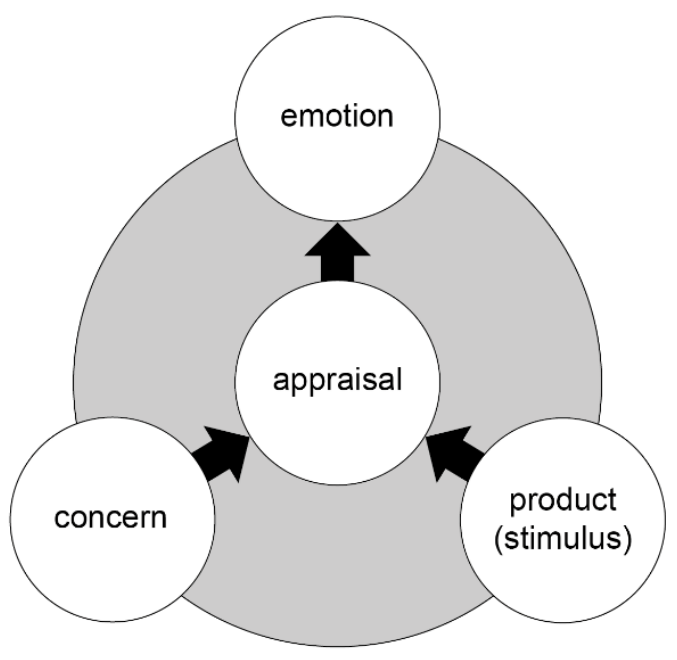

Source: DESMET (2002). 
Figure 2 presents the "idea that a product, when confronted with different concerns by different users, can be evaluated (appraisal) by individuals in different ways, causing equally different emotions" (TONETTO, 2012, p. 100). For the purpose of assessing Hurbanize's user experience, the main concerns are used: "attitudes", "goals" and "standards" (DESMET, 2002; 2007). They are the principles that people carry in the process of emotional assessment and which determine whether a stimulus is relevant or not (TONETTO, 2012). Thus, "attitudes" are the user's inclination to accept or repel objects, people or events - such dispositions may be innate or not, for instance: aversion to bitter tastes or preference for a particular style of a product, respectively; "goals" are the things the user wants to do or see happen - these are goals that can be achieved (wishes) or fulfilled through products (functions), for example: the use of a digital agenda for being able to plan a schedule or buying a bicycle to fulfill the need for transportation; and "standards" are our references, what we believe in, our social norms or conventions about how things should be - while "goals" refer to the things people want to achieve, "standards" refer to the situation in which people think these things should be. Finally, these concerns were crossed by Desmet (2007), based on Jordan (1999) and Norman (2004), with three types of stimuli: "product", "usage" and "consequence", to establish the nine sources of product emotion:

i. Product-Attitudes: products are objects, and all objects are evaluated combining or diverging from our attitudes.

ii. Product-Goals: products can be evaluated as corresponding towards an objective.

iii. Product Standards: people have standards for how products should be, how they should be designed and produced - which puts the product's legitimacy at the first level of stimulation.

iv. Usage-Attitudes: the manipulation of the product can also involve sensations that are evaluated as pleasant or unpleasant.

v. Usage-Goals: when using a product, people are involved in sequences of behavior directed by goals.

vi. Usage-Standards: people have standards for how products should behave when used - involving the performance standards of the product for the second level of stimulation.

vii. Consequence-Attitudes: the consequences of using or owning a product can also be intrinsically pleasant or unpleasant.

viii. Consequence-Goals: the consequence of using or owning the product can be assessed as facilitating the achievement of goals or causing frustration in achieving goals.

ix. Consequence-Standards: people feel the consequence of owning or using a product - the third level of stimulus is related to the effect caused by the product.

With the goal of providing examples, Table 1 refers to the acquisition of a GPS, in which the columns represent the three types of concerns and the lines the three types of stimuli (DESMET, 2007). Finally, this model is used to classify (Table 6), synthesize (Table 7) and interpret (Table 8) the data collected from the use of the Hurbanize app in the urban scene. 
Table 1 - Nine sources of product emotion model

\begin{tabular}{llll}
\hline & Attitudes (A) & Goals (G) & Standards (S) \\
\hline Product (P) & $\begin{array}{l}\text { Enjoying the rounded } \\
\text { shape of the product }\end{array}$ & $\begin{array}{l}\text { Desire to own a route } \\
\text { navigator of a particular } \\
\text { brand }\end{array}$ & $\begin{array}{l}\text { Admiring the factory } \\
\text { for the product's inno- } \\
\text { vative design }\end{array}$ \\
Usage (U) & $\begin{array}{l}\text { Enjoying the gestures } \\
\text { required for selecting a } \\
\text { route }\end{array}$ & $\begin{array}{l}\text { Frustration for not be- } \\
\text { ing able to connect a } \\
\text { music player }\end{array}$ & $\begin{array}{l}\text { Being angry with the } \\
\text { product for not find- } \\
\text { ing signal }\end{array}$ \\
$\begin{array}{llll}\text { Consequence } \\
\text { (C) }\end{array}$ & $\begin{array}{l}\text { Enjoying the sense of } \\
\text { freedom experienced } \\
\text { from the device }\end{array}$ & $\begin{array}{l}\text { Satisfaction by being } \\
\text { able to reach a destina- } \\
\text { tion efficiently }\end{array}$ & $\begin{array}{l}\text { Being proud of my } \\
\text { new established flex- } \\
\text { ibility }\end{array}$ \\
\hline
\end{tabular}
Source: DESMET (2007).

\section{RESEARCH STRATEGY}

Next, an elaboration is made on the techniques for the collection of user perception and on the research strategy.

\subsection{Data collection tool: pick-a-mood}

Pick-A-Mood (PAM) is a tool that allows us to understand how a "technology affects the mood of users and how these states of mind affect user-technology interaction" (DESMET et al., 2016, p. 265). This factor results in a better understanding of the adoption of this technology by people in the long run and can direct designers to create technologies that correspond to the subjective well-being of users (DESMET et al., 2016). Thus, PAM can be applied to evaluate the user while using a product.

It should be noted that mood and emotion are different concepts that share the same characteristic - they are valued affective responses, such as the perception of good or bad, pleasure or pain. Mood states have low intensity, are related to the world, and influence the person's perception and motivation. On the other hand, emotions deal with specific and highly intense feelings, they are related to an object and influence the person's thoughts and behaviors. However, emotion and mood are not independent since they interact dynamically with each other. Emotions can influence mood, such as a joyful sensation can enhance pleasure or the action of offering a drink, such as water and coffee, to improve costumer's mood and, consequently, their emotional responses towards an item on sale. Therefore, mood measurement methods should consider versatile words, such as sad and happy, which have different meanings for mood and emotion, but that are related to each other, facilitating the understanding of the respondents' perception (DESMET et al. 2016).

Under such idea, PAM will be the data collection instrument of this research since it is a quick and intuitive way of measuring user perception towards a technology through easily recognizable visual scales. It is a pictorial scale, inspired by a cartoon, which contains eight distinct moods, plus a neutral state, and can be applied in both qualitative and quantitative research (DESMET et al., 2016). The model (Figure 3) polarizes mood on the horizontal axis in valence (displeasure-pleasure) and on the vertical axis in arousal (low energy - high energy). Therefore, from left to right, the valence of the mood increases positively and from the bottom up, its arousal increases in inten-

HFD, v.10, n 19, p. 03-28, junho 2021 
sity.

Figure 3 - Valence and arousal ratings of Pick-A-Mood expressions

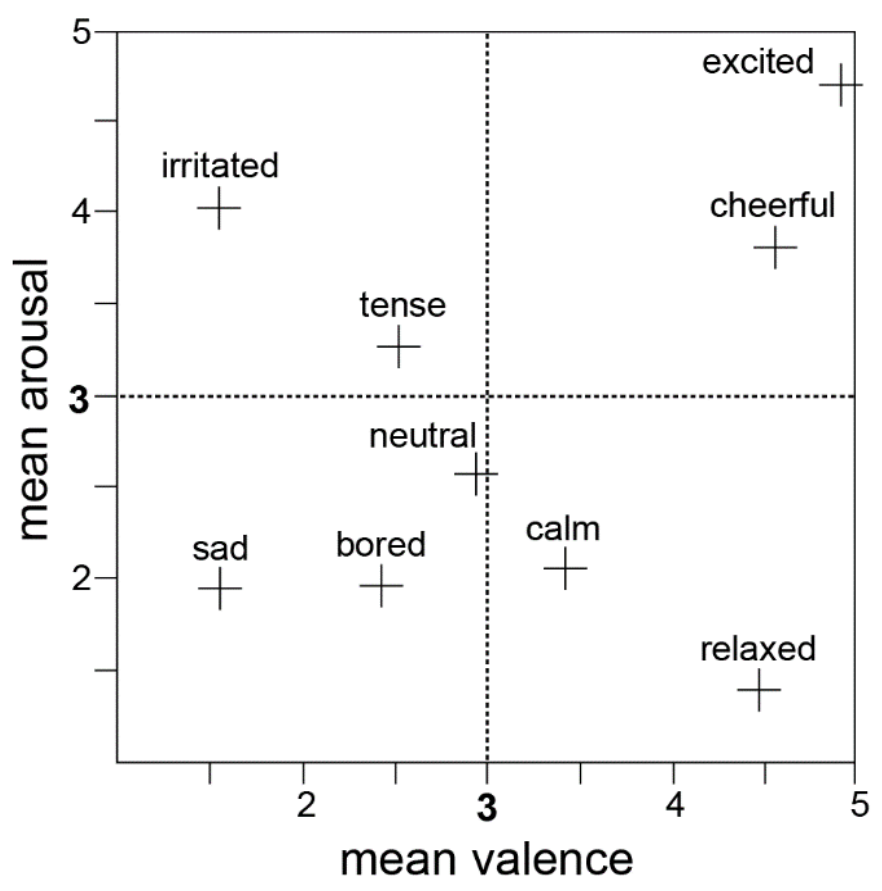

Source: DESMET et al. (2016).

PAM presents three possibilities of characters: a female, a male and a robot (DESMET et al., 2016). Since this research considers the participation of different genres, the neutral robot was chosen as a subject (Figure 4). Furthermore, two questions will accompany PAM: a descriptive question, which aims to provide freedom of expression about one's choice's motivations made on PAM; and the opportunity to mark qualifiers proposed by Preece et al. (2013) about aspects to be desired (satisfying, attractive, exciting, supports creativity, fun, thought-provoking) or to be avoided (tedious, frustrating, childish, unpleasant, artificial, makes someone feel guilty or stupid) for the user experience, in order to improve the understanding of moments of confirmation, contradiction, mistake or doubts presented by users. 
Figure 4-Pick-A-Mood data collection tool

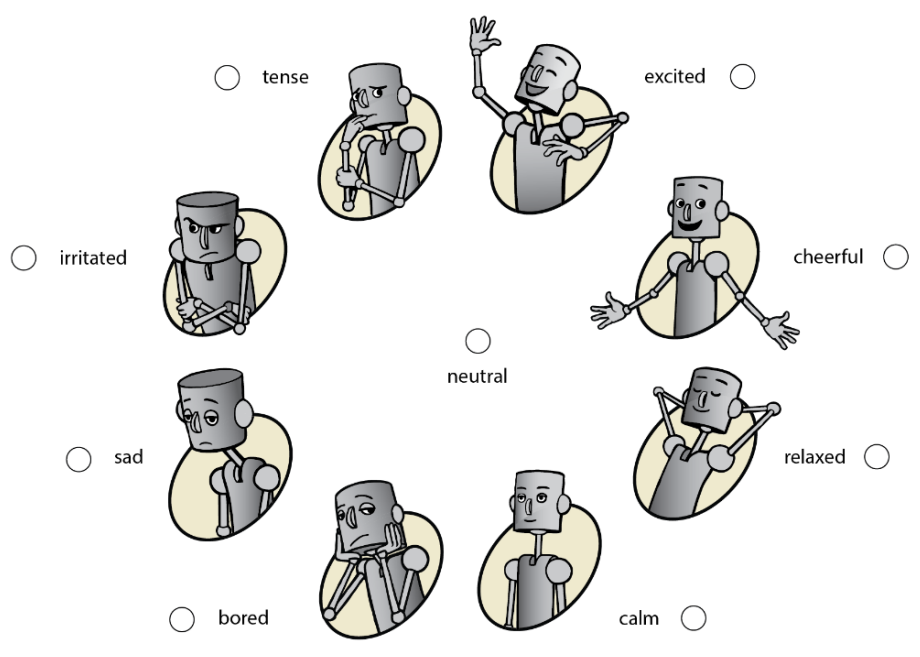

Source: PAM MANUAL (2016).

\subsection{Experiment protocol}

The evaluation of user experience on Hurbanize will occur through moods reported on four moments of the user's journey: Moment 1 (M1), control perception; Moment 2 (M2), place perception; Moment 3 (M3), app perception; and Moment 4 (M4), proposal's perception. Control perception (M1) aims to understand how participants are feeling before carrying out the experiment. Place perception (M2) intends to verify the effect of the space built on the respondents' mood. App perception (M3), which will receive greater attention, addresses the effect of the experience of using the product on the participant's mood. Proposition perception (M4) aims to reflect the effect of the expression of an idea for a given place for the user. Finally, the following application protocol for the experiment was carried out, which comprises four moments and thirteen steps (Table 2).

Table 2 - Moments and experiment protocol

\begin{tabular}{|c|c|}
\hline Moments & Experiment protocol \\
\hline \multirow{4}{*}{$\begin{array}{l}\text { Moment } \\
\text { 1: control } \\
\text { perception }\end{array}$} & $\begin{array}{l}\text { i. Participants were asked to answer the control question: "How are you feeling?", indi- } \\
\text { cating a mood that represents their current state on PAM; }\end{array}$ \\
\hline & ii. Participants were randomly grouped, by lot, into three equity groups; \\
\hline & $\begin{array}{l}\text { iii. Participants were asked to access the app on their mobile devices through the web- } \\
\text { site: https://hurbanize-alfa.firebaseapp.com/\#take-photo; }\end{array}$ \\
\hline & $\begin{array}{l}\text { iv. The task participants were told to do on the Hurbanize app was presented: photo- } \\
\text { graphing a space, painting a sector (optional), applying illustrations and sharing it; }\end{array}$ \\
\hline
\end{tabular}


Moment 2: place perception

Moment 3: app perception

Moment 4: proposition perception v. Each group was conducted to one of the three locations determined by the researchers, so each group stayed in a different location;

vi. Each participant was asked, one at a time, to position themselves on places marked on the floor, to observe the space offered for virtual intervention;

vii. Participants were asked to answer three questions: "How did you feel when viewing the place offered for virtual intervention?", pointing out a mood that represents their current state on PAM; "What are the reasons for you to be feeling that way?", describing the reasons for that state; and click to qualify the place offered for virtual intervention;

viii. It was requested that each participant, one at a time, captured a photograph of the space;

ix. Participants were taken to the classroom;

x. Participants were asked to do their intervention idealizations in the Hurbanize app, on the photograph previously captured and to end the task by sharing it;

xi. Participants were asked to answer three questions: "How did you feel when using Hurbanize?", and point out a mood that represents their current status on PAM; "What are the reasons for you to be feeling that way?", describe the reasons for that state; and click to qualify the Hurbanize app;

xii. The virtual proposals made by the participants were presented through a multimedia projector and direct access to Hurbanize app's database (https://hurbanize-alfa. firebaseapp.com/db16387297384/contacts938729839.html), since at the time of this research the database was not yet available to the public;

xiii. Participants were asked to answer three questions: "How did you feel when visualizing your proposal to modify an urban space?", pointing out a mood that represents their current state on PAM; "What are the reasons for you to be feeling that way?", describe the reasons for that state; and click to qualify your proposal to modify an urban space.

Source: The authors.

\subsection{Places}

In order to make this experiment operational within the conditions available to the researchers, three places were chosen in the vicinity of UFRGS Faculty of Architecture and Urbanism. The chosen places have stimuli understood by the authors as different, one being negative, one neutral and one positive. The place with negative stimulus (P-1), which received Group 1 (G1), comprises a space with no maintenance. In this study, a public walk-in front of the Faculty was chosen, where there are remains of branches and fallen trees, which have not been properly maintained, leaving the sidewalk with obstacles and in the absence of proper landscaping. The neutral stimulus place (PO), which received Group 2 (G2), has no shade, obstacles, or urban furniture. It is configured as a place of passage, and not a place to spend time at, without obvious complications. For this research, a space in the middle of campus was chosen, next to the Faculty of Architecture and Urbanism to simulate a situation of a neutral place in a square. The place with positive stimulus $(P+1)$, which received Group $3(\mathrm{G} 3)$, offers abundant shade, up-to-date maintenance, and absence of obstacles. It is an underutilized place that requires little intervention to become a living space. In this research, a space in the middle of the campus was selected, at the back of the University Radio, to simulate a situation of a not much used space in a park. Finally, Figure 5 shows the map of the experiment to assess user experience. On the map it is possible to recognize the 
places, their stimuli ( $\mathrm{P}-1, \mathrm{PO}$ and $\mathrm{P}+1)$ and their respective groups $(\mathrm{G} 1, \mathrm{G} 2$ and $\mathrm{G} 3$ ) as well as the four moments of perception and the thirteen steps of the experiment.

Figure 5 - Experiment map with places, moments, stimuli, groups, and steps

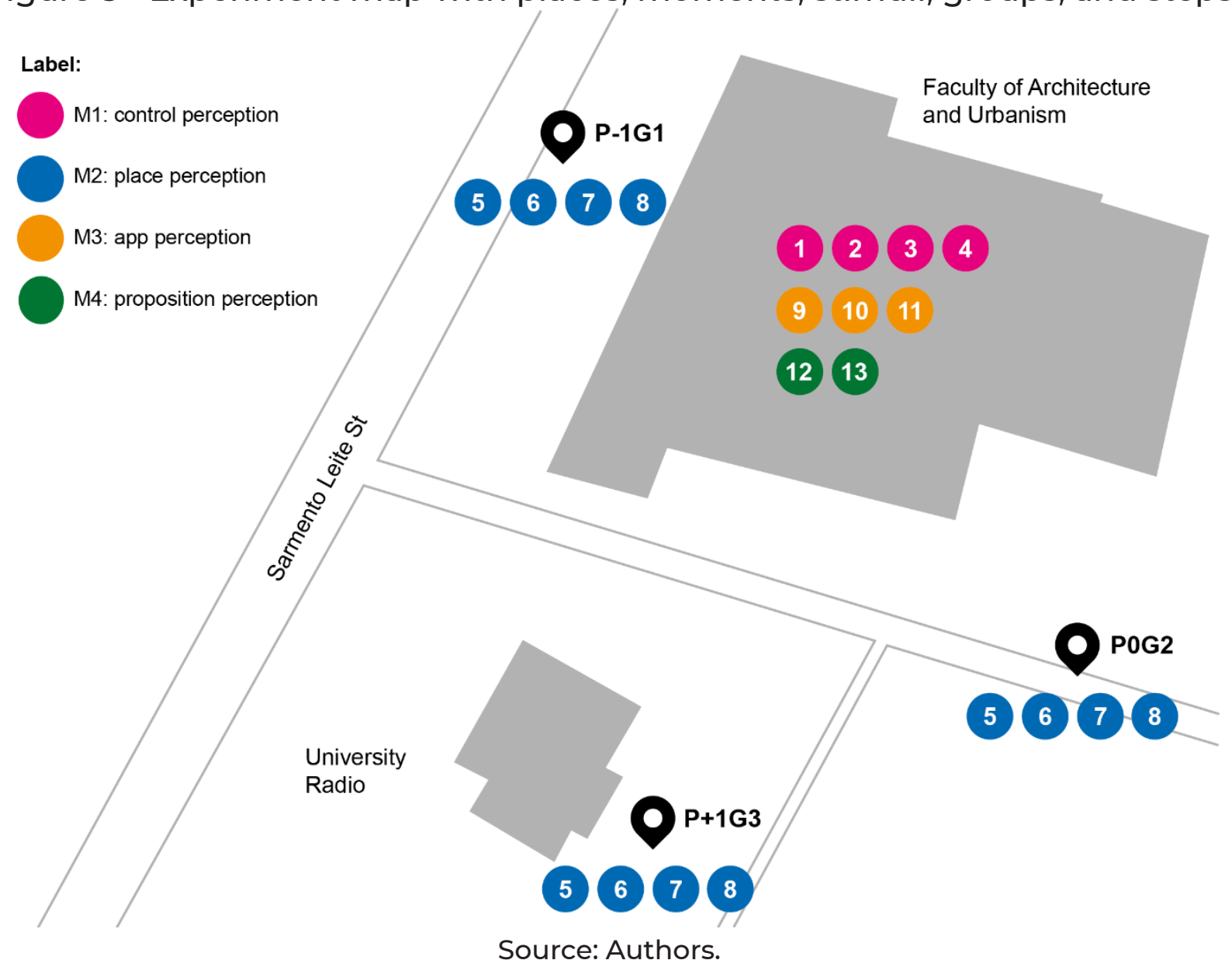

The relationship between the different groups, places, and their stimuli as well as the justified characterization of the stimulus and its image are shown in Table 3. 
Table 3 - Group relationship, place, image, and characterization

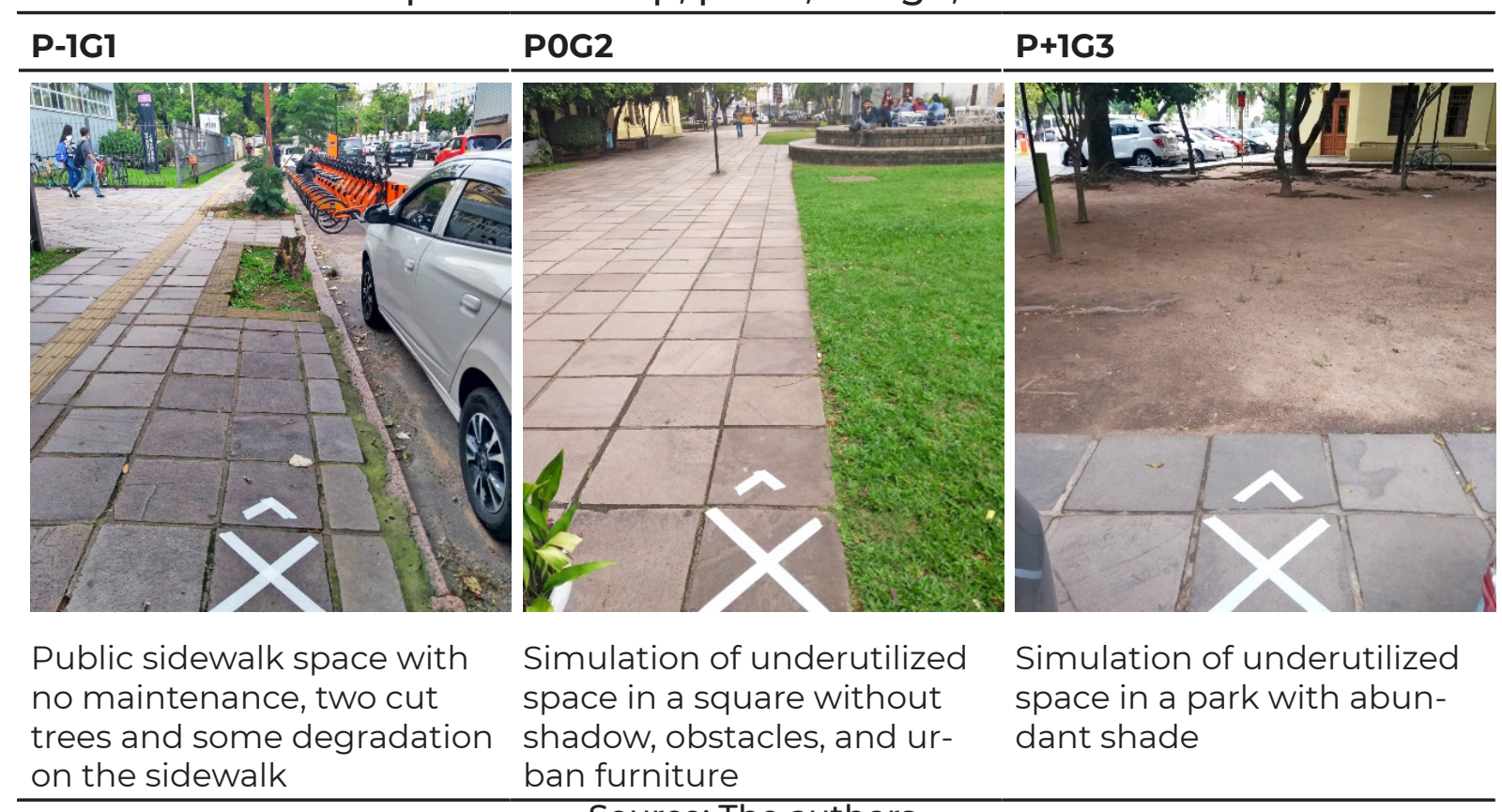

Source: The authors.

\subsection{PARTICIPANTS}

Students from Product Design and Visual courses at UFRGS contributed to the experiment. This audience was chosen due to the convenience and the nature subject of their study, for being able to contribute with perceptions capable of directing the next steps in the development of the PWA Hurbanize. Three invitations were made in three classes of the $1^{\text {st }}, 4^{\text {th }}$ and $9^{\text {th }}$ semesters, so that students could participate spontaneously and voluntarily in the research, by signing a free and informed consent term. Soon afterwards, 30 students accepted the invitation and formed the experiment's sample by convenience. Of these, 18 were female and 12 were male, comprising $60 \%$ and $40 \%$ of the sample, respectively. In the semiannual list, 9 students in the early stages of their courses (coded as "A"), 12 from the middle (coded as "D") and 9 from the final stage (coded as "I") participated in UFRGS design courses (Table 4). Finally, the experiment took place under three applications, each application with its respective class and each class with its respective students separated by lot in three groups (G1: A1, A2, A3, D1, D2, D3, D4, I1, 12 and 13; G2: A4, A5, A6, D5, D6, D7, D8, 14, 15 and 16; and G3: $A 7, A 8, A 9, D 9, D 10, D 11, D 12,17,18$ and 19) so that that each stimulus proposed by the researchers $(\mathrm{P}-1, \mathrm{PO}$ and $\mathrm{P}+1)$ received students from the early, middle and final stages of their courses. 
Table 4 - Distribution of participants by semester and gender

\begin{tabular}{lllllll}
\hline Semester & Female & \multicolumn{3}{c}{ Male } & \multicolumn{3}{c}{ Total } \\
\hline $\mathbf{1}^{\circ}$ (early) & 4 & $13.3 \%$ & 5 & $16.6 \%$ & 9 & $30 \%$ \\
$\mathbf{4}^{\circ}$ (middle) & 7 & $23.3 \%$ & 5 & $16.6 \%$ & 12 & $40 \%$ \\
$\mathbf{9}^{\circ}$ (final) & 7 & $23.3 \%$ & 2 & $6.6 \%$ & 9 & $30 \%$ \\
\hline Total & $\mathbf{1 8}$ & $\mathbf{6 0 \%}$ & $\mathbf{1 2}$ & $\mathbf{4 0 \%}$ & $\mathbf{3 0}$ & $\mathbf{1 0 0 \%}$ \\
\hline \multicolumn{7}{c}{ Source: Authors. }
\end{tabular}

\section{RESULTS AND DISCUSSION}

For the data presentation, the arousal and valence model (DESMET et al., 2016) was used under the radial representation of concentration of the reported moods so that, for each computed report, the diameter of the circle increases once. This representation facilitates the visual analysis of results through the density demonstrated by proportional diameters. Moreover, for $\mathrm{M3}$, the nine sources of product emotion were also employed (DESMET, 2007) to classify and interpret each sentence described by the participants.

\subsection{Moment 1: Control perception}

It is noted in control perception (Figure 6) that $80 \%$ of the answers were around the neutral point, with 8 statements for neutral mood, 6 for tense, 5 for bored and 5 for calm. This concentration expresses arousal and moderate valence, showing apprehension before the application of the experiment.

Figure 6 - Moment 1, control perception

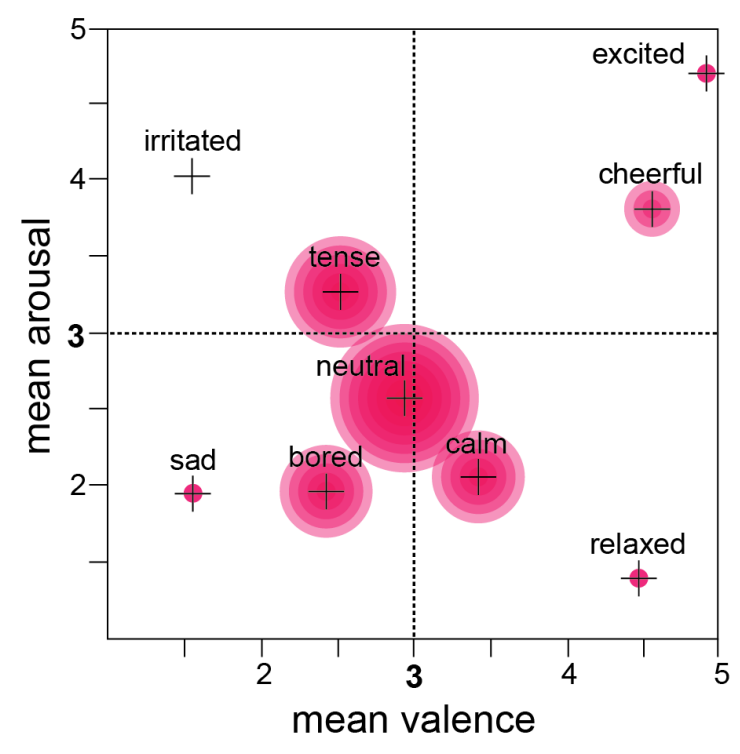

Source: The authors. 


\subsection{Moment 2: Place perception}

With regard to place perception (Figure 7), it was observed that there was a movement from the surroundings of the neutrality of $M 1$ towards relaxation in $M 2$, increasing the valence of participants' mood. At that time, three places were offered with different stimuli, one negative, one neutral and one positive. For the place with negative stimulus (P-1), participants in Group 1 described four negative responses, four neutral and two positive ones, a result that exposes that the negative stimulus was partially perceived by them. The place with neutral stimulus (PO) received two negative perceptions, two neutral and six positive ones from Group 2, a response that indicates that the neutral stimulus was not perceived by the participants. The place with positive stimulus $(P+1)$ obtained from Group 3 included three negative and seven positive statements, a result that presents that the positive stimulus had a corresponding perception.

Figure 7 - Moment 2, place perception

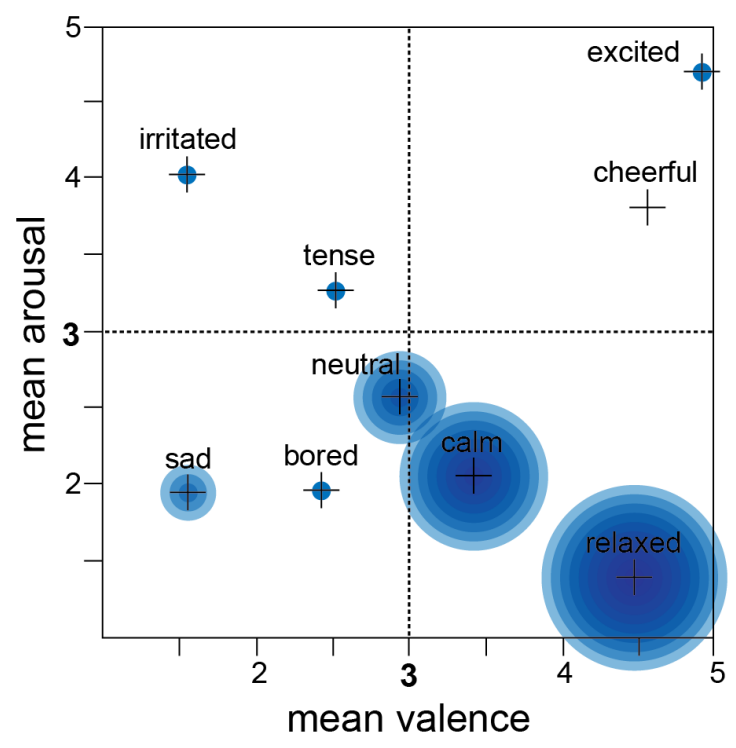

Source: THE AUTHORS.

The following perceptions stood out in the motivations described. For P-1G1: "sad to perceive the state of conservation around the college's entrance" (I3). For POC2: "quiet, pleasant, safe, the weather is good" (A5) and "I feel insecure in the campus in general "(16). For P+1G3:" beautiful, calm place with trees - it is starting rain"(D9). Thus, it is interpreted for the first perception that the person could perceive the place degradation, which is a common walking place for them, and which probably did not consciously affect them before the reflection proposed by the experiment. For the second perception, two opposite situations reflect the concerns of each person, one feels safe and the other feels insecure in the same place, confirming that the appraisals depend on the references (concerns) of each individual. Finally, for the third perception, it indicates that the positive stimulus was perceived as such by the (concerns) of the users, who declared relaxation towards the place. Table 5 synthesizes the M2 results. 
Table 5 - Participant's perception towards the chosen places

\begin{tabular}{lllll}
\hline & Perception & Main argument & Participants & Total \\
\hline P-1G1 & Negative & $\begin{array}{l}\text { Noise pollution, dirty sidewalk, } \\
\text { fallen trees. }\end{array}$ & D2, I1, I2, I3 & 4 \\
\cline { 2 - 5 } & Neutral & Routine, a regular place; & A1, D1, D3, D4 & 4 \\
\cline { 2 - 5 } & Positive & $\begin{array}{l}\text { Trees provide a relaxing environ- } \\
\text { ment; }\end{array}$ & A2, A3 & 2 \\
\hline P0G2 & Negative & Lack of colors, unsafe place. & I4, I6 & 2 \\
\hline & Neutral & Familiar place, walkway; & D8, I5 & 2 \\
\hline Positive & People gathering, safe place; & A4, A5, A6, D5, D6, D7 & 6 \\
\hline P+1G3 & Negative & Uncomplete place, lack of trees. & A7, D11, D12 & 3 \\
\hline & Neutral & - & - & 0 \\
\cline { 2 - 5 } & Positive & Relaxing place, filled with trees; & A8, A9, D8, D9, D10, I7, & 7 \\
\hline
\end{tabular}

Source: The authors.

\subsection{Moment 3: app perception}

PWA Hurbanize's perception can be understood by dividing $90 \%$ of the answers into two groups (Figure 8): one of moderate arousal and slightly positive valence, which addresses neutral and calm moods; and another of high arousal and valence, which refers to cheerful and lively moods, corresponding to $33.3 \%$ and $56.6 \%$ of the sample, respectively. From this data and the comparison between M1 and M2, the app's perception gained in terms of participants' mood in arousal and valence. This movement shows that Hurbanize had a direct positive effect on $56.6 \%$ of users.

Figure 8 - Moment 3, app perception

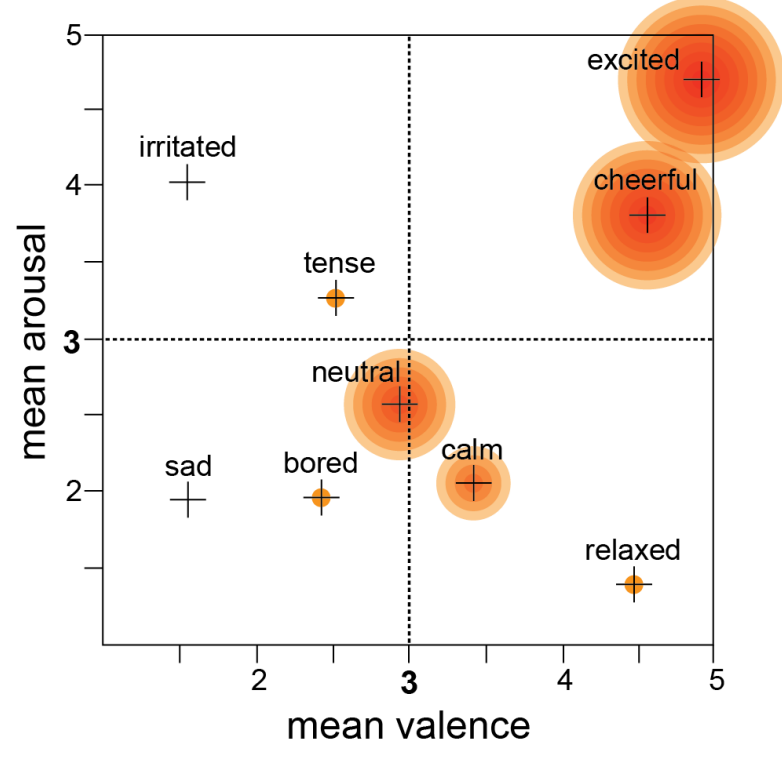

Source: The authors. 
To analyze the qualitative data, there were nine sources of product emotion used as per Desmet (2007), which classified sentences and answers through these codifiers: Product-Attitudes [PA], Product-Goals [PG], Product-Standards [PS], Usage-Attitudes [UA], Usage-Goals [UG] Usage-Standards [US], Consequence-Attitudes [CA], Consequence-Goals [CG], Consequence-Standards [CS], followed by negative (-) and positive $(+)$ symbols, according to the idea expressed in the sentence, as shown in Table 6.

Table 6 - PAM's perception's classification and analysis in M3

\begin{tabular}{|c|c|c|c|}
\hline P/G & Par & PAM & Description \\
\hline \multirow[t]{10}{*}{$\begin{array}{l}\mathrm{P}-1 \\
\mathrm{G}-1\end{array}$} & Al & $\begin{array}{l}\text { Excit- } \\
\text { ed }\end{array}$ & $\begin{array}{l}\text { I enjoyed having freedom to "edit" an environment for better use of a } \\
\text { space with or without users [CA+]. }\end{array}$ \\
\hline & A2 & Bored & $\begin{array}{l}\text { I don't think the place needed more elements; I just made them up } \\
\text { anyways. [US-]. }\end{array}$ \\
\hline & A3 & Calm & I found the app innovative [PS+] and easy to use [UA+]. \\
\hline & D1 & $\begin{array}{l}\text { Cheer- } \\
\text { ful }\end{array}$ & I liked the idea, and the illustrations are satisfying [PA+]. \\
\hline & D2 & Calm & $\begin{array}{l}\text { Using the app was very intuitive [UA+], the only problem was with large } \\
\text { objects, it is harder to use on small spaces [UG-]. }\end{array}$ \\
\hline & D3 & $\begin{array}{l}\text { Neu- } \\
\text { tral }\end{array}$ & $\begin{array}{l}\text { Although it is a good idea, I was not very excited. It has few options of } \\
\text { stickers [PS-]. You can't turn things around [UG-]. }\end{array}$ \\
\hline & D4 & $\begin{array}{l}\text { Cheer- } \\
\text { ful }\end{array}$ & $\begin{array}{l}\text { I really enjoyed the app [PS+], nevertheless, I would create more [PS-] (or } \\
\text { maybe they are simple for loading issues). }\end{array}$ \\
\hline & 17 & $\begin{array}{l}\text { Cheer- } \\
\text { ful }\end{array}$ & $\begin{array}{l}\text { I felt good for being able to interfere on a space where I noticed is- } \\
\text { sues and to show how to improve it [CA+]. Usability is good, it has few } \\
\text { commands and looks like other apps I use [UA+]. I did not find objects } \\
\text { to paste, I noticed that a colleague was using them and that is why I } \\
\text { searched for them. [PG-]. Some perspectives did not look good in my } \\
\text { picture but that did not change the result. [UG-]. }\end{array}$ \\
\hline & 12 & $\begin{array}{l}\text { Neu- } \\
\text { tral }\end{array}$ & $\begin{array}{l}\text { The app seemed simple to be edited and to understand how it works, it } \\
\text { is also easy to see the options available for editing. [UA+]. I was not hap- } \\
\text { py with the final image because of the colors and contrast [CG-]. Illus- } \\
\text { trations could be more realistic [PS-]. Nevertheless, it was very pleasant } \\
\text { to modify the space [CG+]. Moving elements and changing their sizes } \\
\text { reminded me of the features on Instagram's stories [UA+]. }\end{array}$ \\
\hline & 13 & $\begin{array}{l}\text { Neu- } \\
\text { tral }\end{array}$ & $\begin{array}{l}\text { Although the chosen place brings up negative feelings because of its } \\
\text { lack of conservation, the app allows a good user's experience and invites } \\
\text { us to reflect on the environment, helping to neutralize bad feelings. } \\
\text { [CS+]. }\end{array}$ \\
\hline \multirow[t]{3}{*}{$\begin{array}{l}\mathrm{PO} \\
\mathrm{C} 2\end{array}$} & A4 & $\begin{array}{l}\text { Excit- } \\
\text { ed }\end{array}$ & $\begin{array}{l}\text { The app has a nice goal, stimulating creative thinking towards public } \\
\text { space [PS+]. But it still can be improved since it is a beta version. [PS-]. }\end{array}$ \\
\hline & A5 & $\begin{array}{l}\text { Excit- } \\
\text { ed }\end{array}$ & $\begin{array}{l}\text { The app is easy, simple [UA+] with interesting illustrations [PA+] It would } \\
\text { be interesting to be able to save the picture before editing and to im- } \\
\text { port more stickers [UG-]. }\end{array}$ \\
\hline & A6 & $\begin{array}{l}\text { Excit- } \\
\text { ed }\end{array}$ & $\begin{array}{l}\text { The app has great potential due to its creativity (to enable one to alter a } \\
\text { place as one wants) and for the variety of items that are available to the } \\
\text { user [PS+]. }\end{array}$ \\
\hline
\end{tabular}


D5 Cheer- It is quite easy to handle, very intuitive [UA+]. It's fun to think about what ful to add to the landscape. The pen could have more options; I thought I could not use it the way I wanted, so I did not use it at all. [UG-].

D6 Neu- I really liked the app's idea [PS+], but I wanted a brush with a rounder tral edge or a panel to decrease its size [UG-]. I also think the color yellow is missing [PS-]. But it is very easy to use, and the stickers are a big help. [UA+].

D7 Neu- I felt relaxed in the place, but I also noticed that it can be improved tral $[\mathrm{CS}+]$.

D8 Excit- The app is very cool, and it strongly makes you think of ways to improve ed the place observed [PS+].

14 Excit- The app allows us to add objects and use creativity in places that we ed visit daily, but where we are not always comfortable. [CA+]. It made me think what could be different and would make me happier in that place $[\mathrm{CA}+]$.

15 Tense The interface is still too rigid [PA-]. I could not decrease the size of the brush, so it was hard to make the changes I wanted [UG-]. Being able to zoom in the image would have made me feel more comfortable [UG-]. Maybe turning the stickers around would be better, but I am not sure [UG-]. I felt unable to interfere on the scene [CG-].

16 Calm I like the subject and I think many places in Porto Alegre need intervention $[C A+]$. I think the app works very well [UA+], only when I tried to edit an element, I could not change its location [UG-]. It would be interesting if Project students used the app and that governments used those ideas of improvement [PS+], but we know the current situation would not allow it.

$\mathrm{P}+1 \quad$ A7 Excit- I recreated and reframed the meaning of a space; I turned an incom-

G3 ed plete feeling into something happier and more cheerful [CS+].

A8 Neu- The app is cool and allows quick changes in the environment [UA+], but tral it has few options of details [PS-].

A9 Excit- The app allows us to make ideal and optional changes, very useful and ed unique [PS+]!

D9 Excit- I wish the place really had the changes suggested in the app [CS+]. ed

$\mathrm{P}+1$ D10 Cheer- It is fun and you can go far with your creativity because it has lots of opG3 ful tions [CG+]. I missed the ability to rotate the stickers and change them sideways. [UG-].

D11 Calm It is a good experience [UA+] but zooming in and rotating objects would be helpful. [UG-].

D12 Cheer- I enjoyed being able to completely remodel a space [CA+]. The app is ful easy to understand and user-friendly [PA+]. I suggest that objects could be mirrored and rotated [UG-]; and the delete button was confusing, I am not sure how I was able to delete them [PG-]; I found the layers very practical, since the screen is small [UA+]

I7 Re- I was immersed in the activity, not thinking of anything else [CA+]. It is laxed fun and relaxing [CG+]. But it did not work on my cell phone [UG-]. There could be more sticker options to create the environment [PS-]. But it is user-friendly, easy to learn, and the screen only shows the necessary elements, with no distractions [UA+]. 
I8 Cheer- I enjoyed playing and imagining how the place could be improved

ful $\quad\left[\mathrm{CA}^{+}\right]$. The accessibility elements made me think if the place was accessible before [PA+]. The undo button left me insecure, was I going to erase it all or only the last move? [PG-]. I would like to have drawn some flowers too [UG-].

19 Cheer- It was fun to play with the stickers [CG+]. It reminded me of The Sims ful $\quad[C A+]$ I found it great to change the layers, I think I had no difficulty at all $[\cup A+]$.

Source: The authors.

Next, it is used the model of nine sources of product emotion, which matches three kinds of concerns with three kind of stimuli (DESMET, 2007) to position the 72 perceptions, derived from the 30 subjects' impressions, in each square. Note that one same person can appear repeatedly in a same square, since the analysis was made according to the answers, therefore, two different answers can co-exist for the same person. Besides, as shown in Table 7, it is added to the nine sources of product emotion a different classification of perception, according to each one's characteristic, if positive or negative, towards the app.

Table 7 - Summary of perceptions in each sentence

\begin{tabular}{|c|c|c|c|c|}
\hline & Perception & Attitudes (A) & Goals (G) & Standards (S) \\
\hline \multirow[t]{2}{*}{$\begin{array}{l}\text { Product } \\
\text { (P) }\end{array}$} & Positive (+) & D1, A5, D12, I8 & - & $\begin{array}{l}\text { A3, D4, A4, A6, } \\
\text { D6, D8, 16, A9 }\end{array}$ \\
\hline & Negative (-) & 15 & I1, D12, I8 & $\begin{array}{l}\text { D3, D4, I2, A4, D6, } \\
\text { A8, I7 }\end{array}$ \\
\hline \multirow[t]{2}{*}{$\begin{array}{l}\text { Usage } \\
\text { (U) }\end{array}$} & Positive (+) & $\begin{array}{l}\text { A3, D2, 11, I2, I2, A5, } \\
\text { D5, D6, 16, A8, D11, } \\
\text { D12, 17, } 19\end{array}$ & - & - \\
\hline & Negative (-) & - & $\begin{array}{l}\text { D2, D3, 11, A5, D5, } \\
\text { D6, I5, 15, 15, 16, D10, } \\
\text { D11, D12, 17, I8 }\end{array}$ & $\mathrm{A} 2$ \\
\hline \multirow[t]{2}{*}{$\begin{array}{l}\text { Consequence } \\
\text { (C) }\end{array}$} & Positive (+) & $\begin{array}{l}\mathrm{A} 1,17,14,14,16, \mathrm{D} 12 \\
17,18,19\end{array}$ & 12, D10, I7, 19 & 13, D7, A7, D9 \\
\hline & Negative (-) & - & 12,15 & - \\
\hline
\end{tabular}

Hurbanize stimulates the user through its physical configuration ("product"), its interaction project ("usage") and the result obtained after it is used ("consequence"). On the other hand, users understand such stimuli through their concerns of "attitudes", "goals" and "standards". Therefore, the discussion that follows will cover users' concerns towards Hurbanize's stimuli.

Attitudes: on Table 7 it is noticed that the relation between attitudes concern and product stimuli of use and consequence were perceived in a positive way by the participants, since stimuli caused twenty-six positive perceptions and only one negative. With this concern, it is evident that it is related to users' tendency to accept or reject products, people, or events (DESMET, 2007). Hurbanize's good usage stimuli had fourteen positive perceptions with arguments such as: it is intuitive or easy to use $(A 3, D 2,11$, 
12, 12, A5, D5, D6, 16, A8, 17, 19), it offers a good experience (D11) and it's very practical (D12). Another result that highlights positive perceptions occurred in the relation between the concern of "attitudes" and the stimuli of "consequence". There were nine perceptions that mentioned the freedom to alter an environment $(A 1,11,14,14,16, D 12$, 18, 19) and the immersion aspect of the activity (17). Lastly, but not less important, five perceptions were driven towards the relation between concern of attitudes and stimuli of product, being four positive and one negative. Subjects D1, A5, D12 and 18 affirmed they like the app for its formal configuration, for its simplicity, and also for its illustrations, for example: "The accessibility elements made me think if the place was accessible before" (18). This sentence shows that the stimuli of "product" brought up I8's curiosity and made this subject think of Hurbanize not only as an app, but also as a tool for reflecting on all the elements that make up for a city's dynamic, as per Souza Ferreira et al. (2019). On the other hand, in a negative perception, it was said that "the interface is too rigid" (15), highlighting the need for design improvement.

Goals: on Table 7 it is noticed a great number of negative perceptions in the relationship between stimuli of "use" and the concern of "goals". This occurs due to some of participants' expectations (DESMET, 2007). There are two main reasons for this negative perception: lack of the "rotate" function to edit the illustrations and lack of flexibility to change the brush's thickness.

As far as "rotation" goes, this desire from the users was perceived as their wish to correct the illustration's perspective, as told by D3, I1, 15, D10, D11 and D12. Nevertheless, the solution to this problem would be inserting the function "skew", which distorts the illustration's perspective, once simply rotating the illustration would not solve its depth issue. This highlights that the concern of "goals" has a common area with concern of "standards". Users have a belief on how things should be, therefore, they think that rotating the illustration could be the solution for the problem, when in fact it is not. As far as the brush's size goes, users D5, D6, 15 and 18 felt frustrated for not being able to control its thickness and trace. There were also individual frustrations such as the lack of the zoom function (15), the lack of a picture importing function (A5), not being compatible with a particular smartphone system (I7) and the lack of large elements that could become a pattern (D2).

There were three negative perceptions regarding the relationship between the concern of "goals" and the stimulus of "product": lack of clarity in understanding the illustration (I1), delete (D12) and undo (I8) buttons. All these considerations brought up here are opportunities to be considered when developing the final product's configuration. Finally, when observing the relationship between the concern of "goals" and the stimulus of "consequence", one can see four positive and two negative reports. Positive perceptions express fun when using the app, which supports creativity (I2 and D10), is fun (I7 and 19) and relaxing (I7). On the other hand, negative perceptions include: "I was not satisfied with the colors and contrast of illustrations" (I2) and "I felt unable to improve that scenario" (I5), which does not express satisfaction with the final composition.

Standards: these are the user's beliefs on how things should be (DESMET, 2007). Regarding this concern and its relationship with the stimulus of product, the perceptions were quite even, being eight positive and seven negative. Negative perceptions, D3, D4, 12 and 17, argue that the app should have more illustrations. Also, that it should feature the color yellow in the brush (D6), include space for general improvements (A4), it should offer more details to compose the landscape (A8). Positive perceptions reveal 
admiration for the apps' idea: I like the proposal (D4, D6, D8), it has a good ideal (A4), it is innovative $(A 3, A 9)$ it can be an education tool (I6).

In the relationship between the concern of standards and the stimulus of use, A2 reported boredom because the space given did not need improvement. However, A2 belonged to $\mathrm{G1}$, with negative stimulus (11): absence of trees, lack of maintenance on a public sidewalk. This shows that the concern standards of A2 stood out from the stimulus of the use of the app, showing that evaluations (appraisals) depend on the perception of the stimulus by the user through their interests (concerns) (DESMET, 2002; 2007; TONETTO, 2012).

In the relationship between the concern of "standards" with the stimulus of "consequence" and also with the purpose of the app, four perceptions were understood as positive: the app provides a good user experience and reflection on the environment (13), it made me think what could be different in that environment, what would make me happier (14), it made me realize that the place can be changed (D7), I recreated and reframed the space, transformed an incomplete feeling into something happier (A7) and I wanted the place to undergo the changes proposed in the app (D9). These perceptions are aligned with the objectives of the Hurbanize app as elucidated in theory by Souza Ferreira et al. (2019, p.15): "sharpening citizens' values and perceptions through visual language, into what each individual realizes as their own urban ideal", "to encourage citizens' apprehension of space though the arrangement and composition of virtual elements"; and promote awareness for engagement and values formation, becoming a "channel for consultation and exchange amongst citizens and between citizens and specialists".

After the analysis was carried out, Table 8 was created to synthesize the seventy-two perceptions raised in this research, based on Desmet's work (2007), which presents the interpretation of the perceptions allocated in their due relationships between the stimuli provided by Hurbanize and users' concerns as well as the number of perceptions for each relationship.

Table 8 - Interpretation of perceptions

\begin{tabular}{|c|c|c|c|c|}
\hline & $\mathbf{P}$ & Attitudes (A) & Goals (G) & Standards (S) \\
\hline \multirow[t]{2}{*}{$\begin{array}{l}\text { Product } \\
\text { (P) }\end{array}$} & $(+)$ & $\begin{array}{l}\text { Liked the illustrations } \\
\text { and the app's simplic- } \\
\text { ity (4) }\end{array}$ & - & $\begin{array}{l}\text { Liked the proposal and } \\
\text { think it is innovative } \\
\text { (8) }\end{array}$ \\
\hline & $(-)$ & $\begin{array}{l}\text { Disliked the formality } \\
\text { of it (1) }\end{array}$ & $\begin{array}{l}\text { Felt confused about } \\
\text { certain icons (3) }\end{array}$ & $\begin{array}{l}\text { Believed the app could } \\
\text { have more illustrations } \\
\text { (7) }\end{array}$ \\
\hline \multirow[t]{2}{*}{$\begin{array}{l}\text { Usage } \\
\text { (U) }\end{array}$} & $(+)$ & $\begin{array}{l}\text { Liked the task's ges- } \\
\text { tural interaction (14) }\end{array}$ & - & - \\
\hline & $(-)$ & - & $\begin{array}{l}\text { Lack of freedom to } \\
\text { work with illustra- } \\
\text { tions' size or per- } \\
\text { spective (15) }\end{array}$ & $\begin{array}{l}\text { Feels bored because } \\
\text { the place needs no } \\
\text { improvements (1) }\end{array}$ \\
\hline
\end{tabular}




\begin{tabular}{lllll}
\hline $\begin{array}{l}\text { Conse- } \\
\text { quence (C) }\end{array}$ & $\begin{array}{l}\text { (+) } \\
\text { Liked the feeling of } \\
\text { freedom when they } \\
\text { can renovate a land- } \\
\text { scape (9) }\end{array}$ & $\begin{array}{l}\text { Had fun with the } \\
\text { stimulus to one's } \\
\text { creativity (4) }\end{array}$ & $\begin{array}{l}\text { Feels proud for trans- } \\
\text { forming a place (4) }\end{array}$ \\
\cline { 2 - 4 }$(-)$ & - & $\begin{array}{l}\text { Unhappy with the } \\
\text { final design (2) }\end{array}$ & - \\
\hline
\end{tabular}

To understand how the perceptions reported can be related to one another, here are some considerations about Table 8:

i. While nine perceptions of CA+ like the sense of freedom of being able to demonstrate an idea, fifteen perceptions of UG- lack the freedom of a better handling of the brush or the illustration's perspectives (Table 9). This contrast, in the approximate proportion of a positive perception to two negatives between different stimuli and concerns, shows that the factors pointed out in UG- may be influencing the "not" positive perceptions of CA+ as well as the negative perceptions of CG-, which expose a lack of satisfaction with the result of the composition.

ii. While four perceptions of PA+ are interested in the illustrations and the simplicity of the app and eight perceptions of PS+ like the proposal or find the app innovative, one perception of PA- points out a lack of interest due to formal rigidity, three perceptions of PG- feel confusion with some icons and seven perceptions of PS- believe the app could have more illustrations. This balanced contrast between positive and negative perceptions shows that the factors pointed out in PA-, PG- and PS- may be influencing the "not" positive perceptions of PA+ and PS+.

iii. While fourteen perceptions of UA+ like the gestural interaction involved in the task, fifteen perceptions of UG- lack the freedom to better work with the brush or with the illustration's perspectives (Table 9). This direct and balanced relation of the same stimulus shows that UG- may influence the "not" positive perceptions of UA+.

iv. While five perceptions are proud of the apprehension and transformation of the place, one perception presents boredom with the app because it thinks that the place does not need any improvements. This suggests that the perception of US- did not apprehend space in a critical, but in a passive way. This factor shows that reflecting about the urban context is essential for the success of the task. If not, urban space would always be perceived as ideal, without the need for constant improvement, and the purpose of the app would cease to exist. 
Table 9 - Illustration perspective problems and brush problems

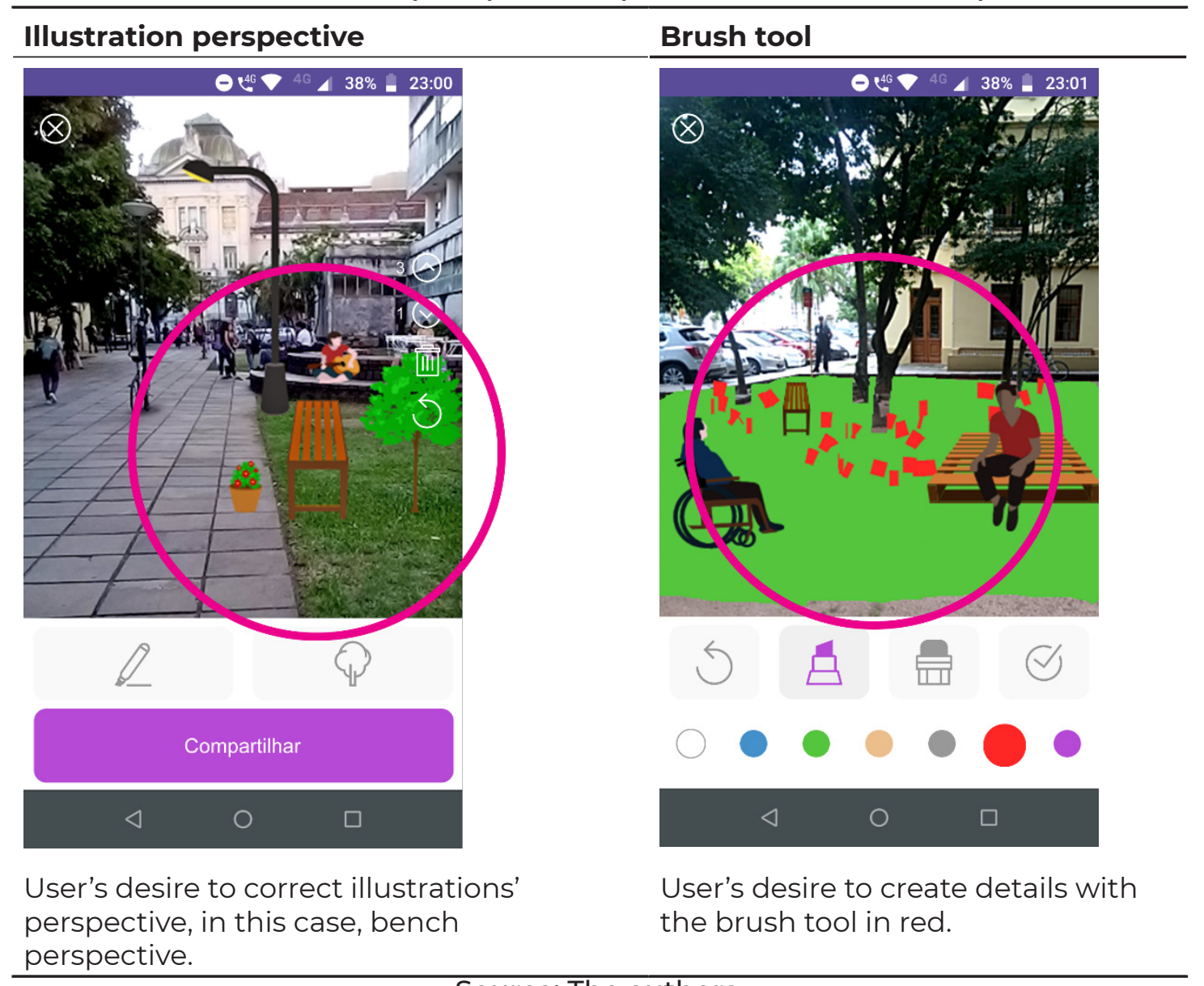

Source: The authors.

Regarding what has been presented so far, next is the evaluation of the perception of the PWA Hurbanize from the perspective of concerns (DESMET, 2002) weighted by the different stimuli (DESMET, 2007):

i. Regarding the concern "Attitudes": approximately $37 \%$ of perceptions accept the Hurbanize app. They like the interaction with the app, whether it is for the purpose involved, for the freedom of expression, the illustrations and simplicity.

ii. Regarding the concern "goals": approximately $28 \%$ of perceptions cannot reach or cannot fulfill what they wish with the current features. They express dissatisfaction with the lack of flexibility to control the brush's detailing and illustration's perspective. They also demonstrate insecurity in reading some icons and editing features. On the other hand, approximately $4 \%$ of perceptions declare having fun with the creative aspect of Hurbanize, stating that they reached their goals despite of the minimal function conditions presented by the app.

iii. Regarding the concern "Standards": perceptions are divided regarding how the app is or should be. Approximately $18 \%$ of perceptions express that the app's proposal should remain the same, be it for the aspect of innovation, for the values of apprehension or because the idea of reconfiguring a landscape. 
In other hand, approximately $10 \%$ of perceptions state that the app should in-

clude more elements or an urban landscape.

Therefore, the perception of the Hurbanize app by users who participated in this research is, respectively: affinity, for the gestural interaction, freedom of expression and simplicity involved; displeasure, due to the few options for detailed editing; credit, for its proposal and novelty; claiming, for more illustrative elements; apprehension, for the misunderstanding of three icons; and enjoyment, for the creative experience offered by the app.

\subsection{Moment 4: proposition perception}

For the last moment in the Hurbanize's user's journey, which is the proposition perception, one can observe in Figure 9 that there was a decrease in arousal combined with an increase in mood valence when compared to moment 3 (Figure 8), which corresponded to $90 \%$ of participants - this factor can be the result of a moment of contemplation. Amongst this 90\% rate (27 answers), 40\% (12) affirmed they felt cheerful with the proposal; 20\% (six) felt relaxed; 13,3\% (four) felt excited; 13,3\% (four) felt neutral; and $3,3 \%$ (one) felt calm. For each one of these moods, the following reports were highlighted, respectively: "I think it helped me to imagine a better-planned and more inclusive future, and also because it was aesthetically pleasing" (D2); "I would really like a space like this to relax" (D11); "I realized that I was able to make changes that add to the comfort and well-being of people who visit the space" (A9); "It was a pleasant experience, the app allows us to give an idea of what could be improved on the place, which is cool, although with few details" (A8); and "reflecting on an ideal environment was another activity that evoked good feelings about the place" (I3). Also, 90\% of perceptions show satisfaction with the proposal and understand that it still is a Beta version, which has room for improvement both in terms of usability and in the amount and quality of illustrated urban elements offered.

Figure 9 - Moment 4, proposition perception

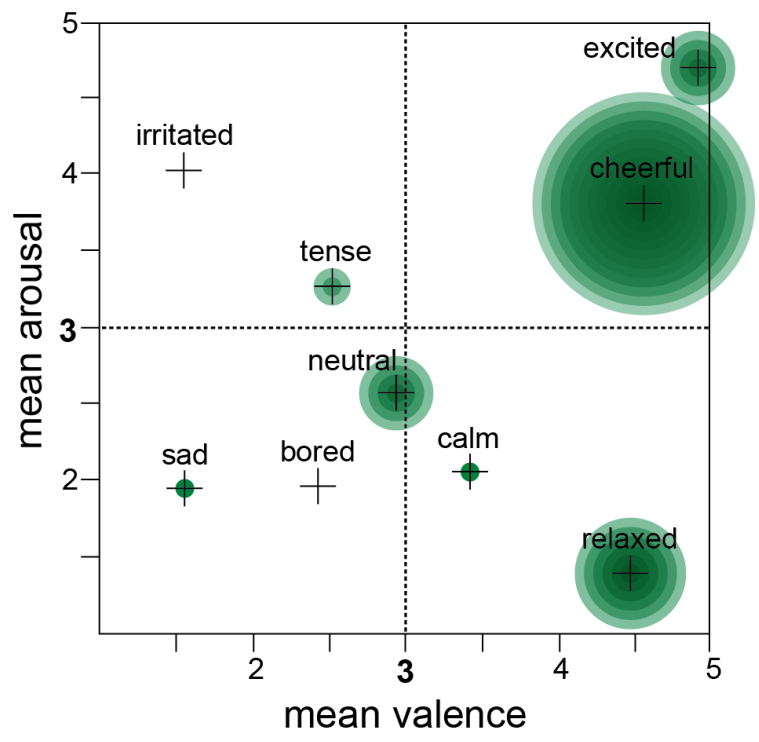

Source: The authors.

HFD, v.10, n 19, p. 03-28, junho 2021 
In contrast to the abovementioned 90\% rate, D7 noted on PAM a "tense" mood, however they described that the motivation for such tension was due to "the need for change in the environment with the possibility of a better environment in the university". It is interpreted, therefore, that the app provided reflection over a location routinely visited by D7, causing some lack of satisfaction for them due to the necessity of improvements on that place. However, this fact shows that D7 was able to perform the task proposed by the app, perceiving it in an instigating way and in support of creativity, according to qualifiers pointed out by the participant under the desirable aspects of user experience present in Preece et al. (2013). Lastly, Figure 10 illustrates the results obtained for each location offered to participants in compositions created with the Hurbanize app.

Figure 10 - Expression of ideas for places and their stimulus
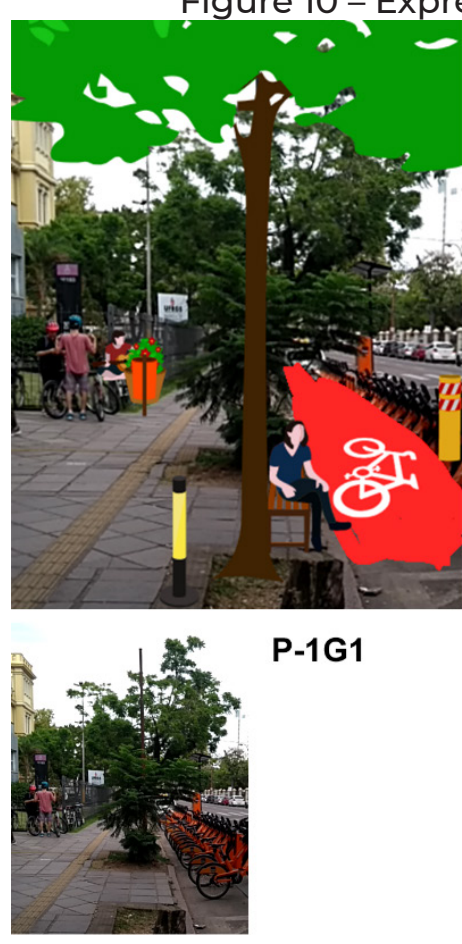

P-1G1

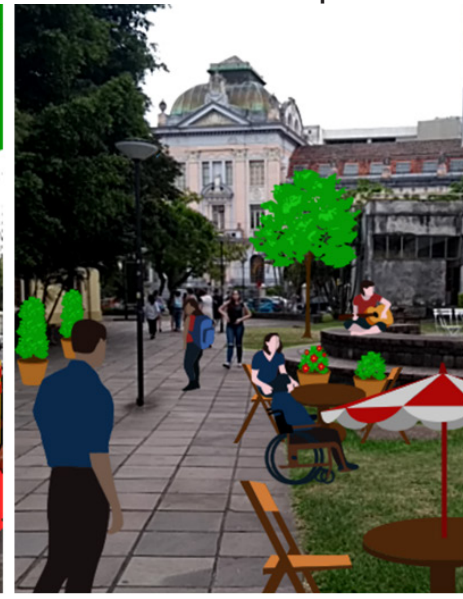

P0G2

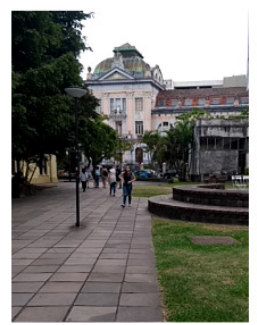

Source: Authors.
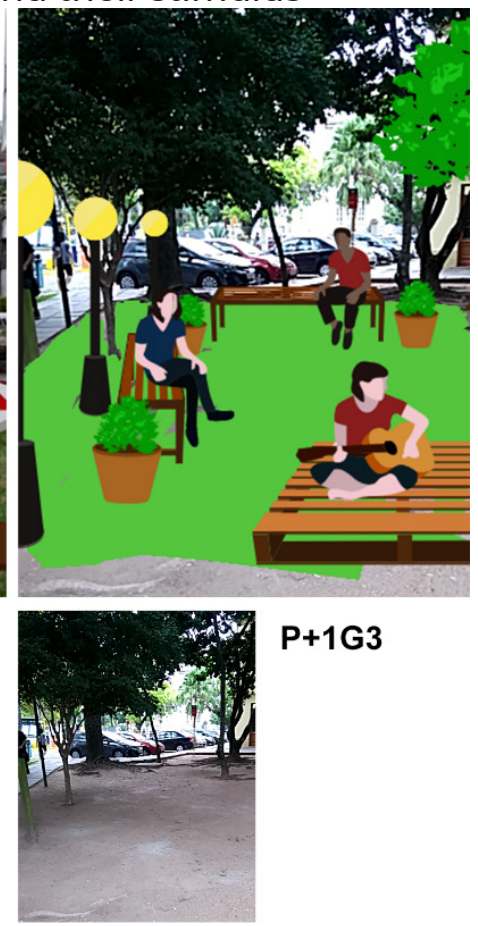

\section{Final considerations}

The ongoing adaptation of urban spaces to people's needs as a context for change are essential for a safe, sustainable, and healthy life. The Hurbanize app can support this process as a channel of expression for citizens' ideas and the deliberation about city's challenges amongst citizens and between citizens and specialists. This study evaluated thirty design students' perceptions about Hurbanize through their user journey. The study was structured in four moments. As part of the final considerations, regarding the perception of control, it was usderstood that there was some discomfort among participants before the experiment was carried out; regarding the perception of place, there was a relaxation of apprehension which previously occurred in the perception of control, followed by a more positive perception than expected for the proposed stimuli, 
which partially worked and should have been proposed with greater discrepancy between them; as for the perception of the app, there was a certain enthusiasm with the app, which was well received by the researched participants. However, for them to perceive a greater value, flexibility issues regarding creation and control of functionalities should be improved or implemented. As for the perception of the proposition, there was a moment of contentment, due to the reflection about change possibilities for the locations featured in the app.

Finally, as a suggestion for future research and aiming to suppress this study's limitations, it is recommended to implement the improvements pointed out in this work, and run this research again to compare both versions; to replicate the study with a probabilistic sample; develop a survey with more discrepant places and verify this effect on user's perceptions; perform a quantitative study in order to define indicators of arousal and valence for the words that summarize users' perceptions in this study, in order to estimate their relationship on the PAM graph; and perform a semiotic analysis of the compositions' results made by the sample.

\section{REFERENCES}

CULLEN, G. Paisagem Urbana. Lisboa: Edições 70, 2008.

DESMET, P. Nine sources of product emotion. In: S. POGGENPOHL (ed.), IASDR: emerging trends in design research. Hong Kong, 2007.

DESMET, P. Designing emotions. Delft, The Netherlands. Doctoral Thesis. Delft University of Technology, 2002. 225 p.

DESMET, P.M.A.; VASTENBURG, M.H.; ROMERO, N. Mood measurement with Pick-AMood: review of current methods and design of a pictorial self-report scale. J. Design Research, Vol. 14, No. 3, pp.241-279, 2016.

BARATA, A. M. F.; FONTES, A. S. Urbanismo Tático: experiências temporárias na ativação urbana. In: III Fórum Habitar, 2016, Belo Horizonte. Anais do III Fórum Habitar 2016. Belo Horizonte: Anais do III Fórum Habitar, 2016.

FUÃO, F. F. Arquitectura como Collage. Tese Doutoral. Escuela Técnica Superior de Arquitectura de Barcelona. Universit Politeecnica de Catalunya, 1992.

FUÃO, F. F. A Collage como Trajetória Amorosa. Porto Alegre: Editora da UFRGS, 2011. GEHL, J. Cidades para Pessoas. 2. ed. São Paulo: Perspectiva, 2013. 262 p.

INSTITUTO TOMIE OHTAKE (São Paulo). Instituto Tomie Ohtake Leroy Merlin Design Award. 2019. Available in: https://www.institutotomieohtake.org.br/en/exhibitions/interna/instituto-tomie-ohtake-leroy-merlin. Accessed in: March 22th, 2020. 
JACOBS, J. Morte e Vida das Grandes Cidades. 3. ed. São Paulo: Editora Wmf Martins Fontes, 2011. $532 \mathrm{p}$.

JORDAN, P. Pleasure with products: Human factors for body, mind and soul. In: W.S. GREEN; P.W. JORDAN (eds.), Human factors in product design: Current practice and future trends. London: Taylor \& Francis, 2004 p. 206-217.

LERNER, J. Acupuntura Urbana. Rio de Janeiro: Record, 2003.

LERNER, J. Entrevista: "Brasileiro fica encantado com cidades europeias, mas não reproduz soluções aqui". [march, 2017]. Entrevistadora: Néli Pereira. São Paulo: BBC Brasil, 2017. Available in: http://www.bbc.com/portuguese/brasil-39238128. Accessed in: July 20th, 2017.

LYDON, M.; GARCIA, A. Tactical Urbanism: Short-term Action for Long-term Change. New York: Island Press, 2015.

LYDON, M.; GARCIA, A. Tactical Urbanists Guide to Materials and Design. New York, 2016. Available in: https://issuu.com/streetplanscollaborative/docs/tu-guide_to_materials_and_design_v1. Available in: May 13th, 2017.

UNITED NATIONS. World Urbanization Prospects 2018. Available in: https://population. un.org/wup/. Accessed in: April 20th, 2019.

NORMAN, D. Emotional design: Why we love (or hate) everyday things. New York: Basic Books, 2004, 272 p.

PAM MANUAL. Pick-A-Mood Manual Pictorial self-report scale for measuring and expressing mood states. Version 02; 03-10-2016. Available in: https://diopd.org/wp-content/uploads/2012/12/PAM-manual_v02.pdf. Accessed in: March 31th, 2019.

PREECE, J. ROGERS, Y.; SHARP, H.; Design de Interação: Além da interação humano-computador. 3ed. Porto Alegre: Bookman, 2013.

SOUZA FERREIRA, F. Hurbanize: uma contribuição do design visual para facilitar a requalificação dos espaços urbanos. 2017. 161 f. TCC (Graduação) - Curso de Design, Design e Expressão Gráfica, Universidade Federal do Rio Grande do Sul, Porto Alegre, 2017.

SOUZA FERREIRA, F.; POZZI, M.; SASTRE, R. Hurbanize: uma Contribuição do Design Visual para Facilitar a Requalificação dos Espaços Urbanos. In: $13^{\circ}$ Congresso Pesquisa e Desenvolvimento em Design, 2019, Joinville. Blucher Design Proceedings. São Paulo: Blucher, 2018. v. 6. p. 2862-2876.

TONETTO, L. A perspectiva cognitiva no design para emoção: análise de concerns em projetos para a experiência. Strategic Design Research Journal, [s.l.], v. 5, n. 3, p.99-106, 26 dez. 2012. UNISINOS - Universidade do Vale do Rio Dos Sinos. 